\title{
A BIBLIOGRAPHY OF GEORGE M. WRONG
}

George McKinnon Wrong (1860-1948) was one of the most significant figures in the development of both the study and the profession of history in Canada. He grew up near Port Burwell and Vienna, Ontario, then a hot bed of evangelical fervour, and entered Wycliffe College in 1879. After graduating in both arts and theology, which he took concurrently, he joined the faculty of Wycliffe. During the next nine years he taught church history, apologetics and liturgics; he also continued his own studies, learning several languages and spending at least two summers studying in Germany and England. After the death of Sir Daniel Wilson in 1892 Wrong was appointed lecturer in history at the University of Toronto.

In 1894 Wrong became Professor of History, a position he held until 1927. As head of the department he brought to Toronto many young graduates of Oxford. Together they altered the Department of History, bringing about such changes as: the teaching of Canadian history; instruction in small groups, based on the Oxford Tutorial system; program options of English and History, and Classics and History; the Historical Club; and, in the 1920's, a mature program of graduate studies. Many of the traditions begun under Wrong are cherished still at Toronto and at other universities. The list of historians who learned something of the breadth and the art of history from Wrong's department includes: George Brown, A.L. Burt, J.B. Brebner, C.N. Cochrane, D.G. Creighton, G.P. De T. Glazebrook, A.R.M. Lower, E.W. McInnis, D.J. McDougall, C.W. New, W.N. Sage, F.H. Soward, F.H. Underhill, and W.S. Wallace.

Wrong was one of several men who stimulated and presided over the growth of the historical profession in Canada. In addition to expanding the undergraduate and graduate program, Wrong helped establish the Champlain Society, and was the founder of the Review of Historical Publications Relating to Canada, which became the Canadian Historical Review. Wrong also worked with a variety of advisory committees which ensured the existence and growth of the Public Archives. Wrong and his colleagues wrote textbooks that were used in every province in Canada, and Wrong's own monographs and popular history series stimulated public interest in Canadian history.

As the son-in-law of Edward Blake, Wrong had the ear of many significant people. He used these contacts, and was used by them, to foster a number of political and social movements. Wrong worked particularly hard to improve Canada's relations with England (Round Table Movement), to encourage better relations and understanding between French and English Canada, and to reduce anti-British opinion in the United States. He also was an active supporter of Anglican schools such as Havergal and Bishop Ridley; social institutions such as 
Ketchum Hall, the Grenfell Mission, the Ontario Red Cross; and political groups such as the Canadian Institute for International Affairs, and the League of Nations Society. He corresponded with political leaders, public figures and historians all over North America and Europe, and he was in constant demand as a speaker. His bibliography indicates the extent of his teachings.

For a more complete description of the life of Wrong see the author's PhD dissertation "And Gladly Teach: G.M. Wrong and the Department of History at the University of Toronto". (Michigan State, 1977); the PhD thesis by Alan Bowker mentioned below; and W.S. Wallace, "The Life and Work of George M. Wrong" Canadian Historical Review 29 (September 1948) 229-37.

In addition to the published works of George Wrong this bibliography contains references to addresses he made, to editorial comments on his statements, and to some unpublished but dated essays. These latter items were included because they provided a clue to what concerned Wrong at a particular time and because at least two were presented to radio audiences.

The material is listed chronologically. Within each year the first items are books written or edited by Wrong, followed by other items for which only the year of publication was available. Then come articles, reviews, addresses and letters-to-editors, intermingled chronologically. Some addresses were published, or were presented several times; where this occurs all items are listed under the earliest date. Editorial or individual responses to Wrong are placed with the item to which they refer; occasionally an article about Wrong appears by itself.

The material here was drawn from several sources. "A Bibliography of the Works of George M. Wrong" compiled by Katherine Wales and E. M. Murray (Canadian Historical Review 29 (September 1948) 238-9) lists books and some articles. An earlier version by E. M. Murray, "A Bibliography of the Works of George MacKinnon Wrong" (1938) is available at the University of Toronto Library School; it contains references to reviews of Wrong's books and to the printing history of a few books and pamphlets. Alan Bowker has an extensive list of works by and about Wrong and some of his contemporaries in "Truly Useful Men: Maurice Hutton, George Wrong, James Mavor and the University of Toronto, 1880-1927" (unpublished PhD thesis, University of Toronto, 1975). Indexes and catalogues in the Canadian Historical Review, the American Historical Review, The New York Times, the National Library in Ottawa and libraries in Toronto were also used to locate Wrong's work. Newspaper clippings (Biographical File, University of Toronto Archives) provided most of the information regarding addresses and editorial reactions. It should be pointed out that about a dozen of these were not verified; this might be the result of mislabelling or of microfilming a different edition than the one from which the clipping was taken. The reader should also be aware that no attempt was made to search all newspapers for accounts of Wrong's addresses. The University of Toronto Archives also has, in the Department of Extension Geographical File, a list of lectures delivered in various Ontario cities. Other addresses were located in the Wrong Papers held by the University of Toronto, Department of Rare Books and Special Collections. Many references to Wrong's addresses, articles, and letters-to-editors were found in the correspondence of his friends in the University to Toronto Library, the Public Archives of 
Canada, the Library of Congress, and letters in the possession of his daughter, Mrs. C.H.A. Armstrong of Toronto.

All of the items listed here have been verified, except where otherwise indicated. Unverified material falls into three categories. First are those items which I have not seen but have no reason to doubt; these are arranged in chronological sequence with other items and are enclosed in square brackets. Second are items such as addresses or articles which are mentioned fairly specifically in a letter or some other source, but for which no additional corroboration was available; these are identified as unverified, and are placed at the end of the appropriate year. Third are items which I felt could not be included here at all; these include references which were too vague to be located, and the references in the biographical file in the University Archives which could not be verified.

Much had to be omitted from this bibliography: unpublished material, such as essays and diaries in the University of Toronto Library and in the possession of Mrs. Armstrong; and unsigned material, such as anonymous reviews in the Review of Historical Publications Relating to Canada. Some material is known to exist but was not located, such as addresses to Canadian Clubs in cities outside of Toronto, and articles in Parish and Home, for which only a few volumes were available in the Anglican Church Archives and the New York Public Library. Another area of omission is biographical data such as service on editorial boards, eulogies, minor notices in newspapers, and reviews of Wrong's books.

In the preparation of this bibliography I was greatly assisted by previous collections, by librarians and archivists all across Canada and in England and the United States. In particular I would like to thank Mrs. C. H. A. Armstrong; Dr. Alan Bowker; Dr. T. R. Millman, Wycliffe College; Dr. Norman Penlington, East Lansing, Michigan; and Mr. Andy Birrell, Ottawa. The staff in the Archives, Reference Room and Microfilm Room of the University of Toronto Library were exceptionally helpful and patient.

It would be appreciated very much if any errors or omissions in this bibliography could be brought to the attention of the Archivist, University of Toronto Library.

Abbreviations used in this bibliography:

Journals

AHR American Historical Review

CHR Canadian Historical Review

EC Evangelical Churchman (Toronto)

PH Parish and Home (Toronto)

UTM University of Toronto Monthly

Toronto Newspapers

Daily News The Toronto Daily News

Globe The Globe

Mail The Daily Mail and Empire

Star The Toronto Daily Star

Telegram The Telegram

Varsity The Varsity (University of Toronto)

World The Toronto World 
Reference

RBD Department of Rare Books and Special Collections,

University of Toronto Library

UTA University of Toronto Archives

\section{4}

Address: at St, Paul's, Toronto, [ see Evangelical Churchman 9 (11 September 1884) 212].

\section{6}

Review: F.R. Wynne, The Joy of the Ministry: an endeavor to increase the efficiency and deepen the happiness of pastoral work, EC 10 (8 April 1886) 580 .

Letter: "New Lectureship in Oriental Languages" The Varsity, 6 ( 3 April 1886) 240 [reply "Our Critic Criticized", Ibid. 224-235 (sic.). Both the microfilm in the University of Toronto Library and the original held in the Archives for this issue have pages missing; in addition the pages are misnumbered. A more complete collection of The Varsity for the year 1886 is available at York University, Ducharme Collection.]

Review: Right Hon. Lord Robert Montague, Recent Events and a Clue to Their Solution, EC 11 (19 August 1886) 170.

Review: Henry Footman, Reasonable Apprehensions and Reassuring Hints, EC 11 (18 November 1886) 326.

\section{8}

Letter: "The Political Science Professorship", The Varsity 8 (25 February 1888) 169.

Letter: "City Missions", $E C 12$ (1 March 1888) 511.

Letter: "Historical Theology in Wycliffe College", EC 12 ( 4 October 1888) 259.60 .

\section{9}

Letter: "Privy Council Ritual Decisions", EC 14 (5 December 1889) 368.

Letter: "Privy Council Judgments in Ritual Matters", EC 14 ( 7 November 1889) 319 [ reply EC 14 (21 November 1889) 343] .

Article: "St. Columba and Iona", EC 14 (19 December 1889) 396-7.

\section{0}

Letter: "Patronage", EC 14 (20 March 1890) 551.

Article: "The Trouble at St. Judith's", Parish and Home 1 (December 1890) 1-2 [satirical sketch].

Article: "The Old-time Christmas Spirit", $P H 1$ (December 1890) 2-3.

Article: "Thoughts for the Thoughtful", PH 1 (December 1890) 4.

Address: 1 December 1890 (at St. Peter's Church, Toronto) [see EC 15 (11 December 1890) 374]. 
Letter: "The North End Club", EC 15 (5 February 1891) 476.

Article: "German Student Life" (Parts I and II), Varsity 10 (10, 17 March 1891) 222-23, 234-35.

Article: "The Study of History", 18 April 1891 [ abstract in Transactions of the Canadian Institute 4th Ser., Vol. II (1890-91) 39-40].

Unverified Article: "A Child's Mission" [a story in 12 parts] PH 1 (January to December 1891) [ signed "W", possibly Wrong].

1892

Book: The Crusade of MCCCLXXXIII, Known as that of the Bishop of Norwich, London: James Parker and Co., 1892. pp. viii, 96.

\section{3}

Article: "Feeling and Faith", $P H 3$ (February 1893) 2-3.

Letter: "A Parish Magazine", EC 18 (23 February 1893) 88.

Article: "Growth", PH 3 (November 1893) 2-3.

\section{4}

Pamphlet:Application and Testimonials of George M. Wrong, B. A. for the Post of Professor of History in the University of Toronto, Toronto, 1894.

Address: "The Fall of Rome" [ Saturday public lecture ] 3 February 1894 [ see Varsity 13 (7 February 1894) 5].

About: "A Recent Appointment", editorial, Varsity 14 (17 October 1894) 12; W. A. Braun, letter and editor's reply, Ibid (14 November 1894) 50-1; William Dale, Letter, Globe (9 February 1895) 5.

\section{5}

Address: "Historical Study in the University and the Place of Medieval History", 12 January 1895. [ Inaugural lecture; see EC 21 (14 February 1895) 74]; published under the same title, Toronto: Bryant Press, 1895.

Address: "University Historical Study" [ one of a series of Saturday public lectures delivered during the session 1894-95].

Letter: "The University Trouble", The Globe (4 February 1895) 2 [ see also: letter from B. E. Walker, Ibid., p. 3; editorials in Varsity 14 October 1894) passim; The Evening Star, (4 October 1894) 1].

Address: "The Clergyman in his Study", 1 October 1895 [on opening Wycliffe, see Daily Mail and Empire (2 October 1895) 2]

Address: "The Teaching of Epictetus", 3 December 1895, to Classical Association of University College [Department of Rare Books and Special Collections, University of Toronto Library].

\section{6}

Review: A.G. Bradley, Wolfe, American Historical Review 1 (January 1896) 355-356.

Address: "Stoic Ethics", 7 February 1896, to Philosophical Society [ summary $\mathrm{RBD}]$. 
Review: H. Lorin, Le Comte de Frontenac: Etude sur le Canada Français a la Fin du XVII Siecle, AHR 1 (April 1896) 545-547.

Review: W. Kingsford, The History of Canada, Vol. VIII, 1808-1815 AHR 1 (April 1896) 550-553.

Review: [ signed "G.M.W.", M.R. de Kerallain, La Jeunesse de Bougainville et la Guerre de Sept Ans, AHR I (April 1896) 576-5771.

Address: "The Discovery of the Cabots" April 1896, Ontario Education Association.

Address: "The Cabots" 28 March 1896, Canadian Institute [ see EC 21 (2 April 1896) 168].

Review: E. Richard, Acadia: Missing Links of a Lost Chapter in American History, AHR 2 (October 1896) 159-161.

Unverified Address: "Feudalism in Canada", December 1896, Ontario Education Association.

1897

Edited: Louisbourg in 1745: The Anonymous Lettre d'un Habitant de Louisbourg (Cape Breton) containing a narrative by an eye-witness of the seige in 1745, edited with an English translation by G. M. Wrong. Toronto: Warwick Brothers and Rutter 1897.pp. 74.

Edited: Review of Historical Publications Relating to Canada [ of the year 1896] Vol. I. Toronto: William Briggs 1897. pp. 190.

Letter: "The Working Boys' Home” EC 22 (25 February 1897) 125.

Article: “The Queen's Reign" PH 8 (June 1897) 62-3.

Review: "Current Skepticism", Coulson Kernahan, The Child, the Wise Man, and the Devil, EC 22 (5 August 1897) 494.

Review: "The Christian", Hall Caine, The Christian, EC 22 (21 October 1897) 668-669.

1898

Edited: (assisted by H. H. Langton) Review of Historical Publications Relating to Canada [ of the year 1897] Vol. II. Toronto: William Briggs, 1898. pp. 238.

Article: "History in Canadian Secondary Schools", American Historical Association, Annual Report (1898) 551-5.

Letter: "The Revival of Faith" EC 23 (6 January 1898) 18.

Address: "Normans and their Architecture" February 1898, Women's Art Association [ see EC 23 (10 February 1898) 91].

Address: [on French Revolution, 11 February 1898. One of a series of Extension lectures, Public Library, Hamilton, see EC 23 (17 February 1898) 107].

Address: "The Relative Educational Value of History", 13 April 1898, Ontario Education Association [ see EC 23 (4 August 1898) 491-2] .

Unverified Address: "The Renaissance in Florence" (1898) Women's Art Association [ see Mail (2.12.98)] .

Unverified Address: "Oliver Cromwell", Milton, Ont. [1898-99 Extension Department Lecture Series] . 
Edited: (with H. H. Langton) Review of Historical Publications Relating to Canada [ of the year 1898] Vol. III. Toronto: William Briggs, 1899. pp. 225.

Address: [on flag celebrations] 16 February 1899, Ontario Historical Association. [ see Globe (17 February 1899) 41 .

Review: J. E. Roy, Histoire de la Seigneurie de Lauzon, 1897, 1898 AHR 4 (April 1899) 578-80.

Unverified Address: "Cromwell", Dundas, Ont. [1899-1900 Extension Department Lecture Series].

1900

Edited: (With H. H. Langton) Review of Historical Publications Relating to Canada [ of the year 1899] Vol. IV. Toronto: William Briggs, 1900. pp. 229.

\section{1}

Edited: (with H. H. Langton) Review of Historical Publications Relating to Canada [ of the year 1900] Vol. V. Toronto: William Briggs, 1901. pp. 226.

Address: "What the Historian Should and Should Not Attempt" 14 January 1901. [see Varsity 20 (15 January 1901) 191].

Article: "The Constitution of the University of Toronto" Varsity 20 (12 February 1901) 239-40.

Address: [ The Sphere and Methods of the Historian ] 5 March 1901, Canadian Club [see Star (6 March 1901) 1].

\section{2}

Edited: (with H. H. Langton) Review of Historical Publications Relating to Canada [ of the year 1901] Vol. VI. Toronto: William Briggs, 1902, pp. 226.

Review: Sidney Lee, ed., Dictionary of National Biography, Supp., AHR 7 (April 1902) 558-90.

Symposium: (with Adam Shortt, W.S. Milner, Rev. Oswald Rigby) "What Should be Expected in History of the Student on Entering the University?", 3 April 1902,Ontario Educational Association [ see Ontario Educational Association Proceedings, Toronto: Briggs (1902) 27 ].

Review: Fitzgerald Molloy, The Queen's Comrade: the life and times of Sarah, Duchess of Marlborough, AHR 7 (July 1902) 767-8.

Article: "Professors and Undergraduates" Varsity 22 (14 October 1902) 3.

\section{3}

Book: The British Nation, A History, Twentieth Century Text Books. New York: Appleton, 1903; Toronto: Morang, 1904. pp. xxxii, 616.

Edited: (with H. H. Langton) Review of Historical Publications Relating to Canada [ of the year 1902] Vol. VII. Toronto: William Briggs, published by The Librarian, 1903. pp. 222.

Address: "Ideals of the Ministry", 3 March 1903, Wycliffe College [ see Varsity 22 (11 March 1903) 316]. 
Article: "Text-books on British History" Educational Monthly of Canada 25 (misnumbered 26) (June 1903) 257-60.

Review: Louise Creighton, ed., Historical Essays and Reviews by Mandell Creighton, AHR 8 (July 1903) 734-36.

Address: "The Teaching and Influence of F. W. Robertson and Phillips Brooks" Wycliffe College Alumni Association, 30 September 1903.

Article: "The Student Life", Varsity 23 (14 October 1903) 1-2.

\section{4}

Edited: (with H. H. Langton) Review of Historical Publications Relating to Canada [ of the year 1903] Vol. VIII. Toronto: Morang, published by The Librarian, 1904. pp. 225.

Review: E. Porritt, The Unreformed House of Commons: Parliamentary Representation before 1832, AHR 9 (April 1904) 565-68.

Review: J. Morley, The Life of William Ewart Gladstone, AHR 9 (April 1904) 591-95.

Article: "The Conferring of a Degree upon the Archbishop of Canterbury", University of Toronto Monthly 5 (October 1904) 16-17.

Unverified Address: [ Japan] in Napanee. [ See Department of Extension memo n.d. UTA, A73.018, Box 2/8.].

\section{5}

Book: The Earl of Elgin. London: Methuen 1905; Toronto: Morang, 1906. pp. xii, 300.

Edited: An English History by E. S. Symes Adapted for Use In Canadian Elementary Schools. Toronto: Copp, 1905. pp. vi, 286.

Edited: (with H. H. Langton) Review of Historical Publications Relating to Canada [ of the year 1904] Vol. IX. Toronto: Morang, 1905. pp. 240.

Article: "A Residence for Men", Varsity 24 (12 January 1905) 1.

\section{6}

Edited: (with H. H. Langton) Review of Historical Publications Relating to Canada [ for the year 1905] Vol. X. Toronto: Morang, 1906. pp. 221.

Review: $\quad$ R. G. Thwaites, France in America, 1497-1763, AHR 11 (January 1906) 413-16.

Article: "The Late Principal Sheraton" UTM 6 (March 1906) 115-18.

Review: J.N. Larned, Seventy Centuries of the Life of Mankind, 2 Vol., AHR 11 (April 1906) 707.

About: Stuart Calais, "Canadian Celebrities: No. 70 - Professor George M. Wrong” The Canadian Magazine 27 (July 1906) 208-10.

Review: L. T. Hobhouse and J. L. Hammond, Lord Hobhouse, a Memoir, AHR 12 (October 1906) 141-43.

Letter: "Canada and the United States", The Spectator (London) ( 17 November 1906) 783-4. [ Re: Newfoundland and Alaska; editor's reply in Ibid., 784. See also Mail (19 November 1906) 12; Globe (23 November 1906) 4; letter defending Wrong by C.D.B., Globe ( 8 December 1906) 14.] 
Edited: (with H. H. Langton) Review of Historical Publications Relating to Canada [of the year 1906] Vol. XI. Toronto: Morang, 1907. pp. 225.

Review: S. J. Reid, Life and Letters of the First Earl of Durham, 1792-1840, AHR 12 (April 1907) 637-40.

About: "A Social Settlement" Canadian Courier 2 (26 October 1907) 15.

Article: "Goldwin Smith Today: The Evening of his Life in Toronto", Boston Evening Transcript (26 October 1907).

Letter: "What Canada Owes to the Careful Policy of the British Diplomat", Globe (26 December 1907) 6.

\section{8}

Book: A Canadian Manor and its Seigneurs, the Story of a Hundred Years, 1761-1861. Toronto: Bryant Press, 1908. pp. xiv, 295. (Reprinted Toronto: Macmillan, 1926. pp. xvii, 295.)

Edited: (with H. H. Langton) Review of Historical Publications Relating to Canada [of the year 1907] Vo. XII. Toronto: Morang, 1908. pp. 212.

Address: 23 January 1908 [Literary and Historical Society, Murray Bay] [The Toronto World (24 January 1908) 1.].

Article: "Champlain in English", Bulletin de la Société de Géographie de Québec 3 (July 1908) 37-42.

\section{9}

Edited: (with H. H. Langton) Review of Historical Publications Relating to Canada [of the year 1908] Vol. XIII. Toronto: Morang, 1909. pp. 198.

"Prefatory Note": Gordon B. Thompson, The Kulturkampf: an essay. Toronto Macmillan (1901) iii-xii.

Address: "The University Man in Politics", 5 February 1909, History Society of University College. [ See Varsity 28 (19 February 1909) 1.]

Address: "Erasmus and His Place in the Reformation Movement", 5 October 1909, Wycliffe College. [See Varsity 29 (8 October 1909) 3.]

Address: [On Christian education] ; 27 October 1929, Wycliffe Chapel. [See Varsity 29 (29 October 1909) 3.]

Article: "Report of the Committee appointed to enquire in regard to a possible College for Women", UTM 9 (June 1909) 286-89. [See "Reply of the Alumnae" Ibid. 289-91.]

Article: "The Attitude of Canada", The Nineteenth Century and After 66 (October 1909) 704-15; [also in The Living Age, 7th Series, 45 (1909) 387-96].

Article: “A College for Women" UTM 10 (November 1909) 4-7.

Address: "Canadian Nationalism and the Imperial Tie", 29 December 1909, American Economic Assoc., American Historical Assoc. [See New York Daily Tribune (30 December 1909) 3; "Professor Wrong is Wrong" The Mail and Empire (4 January 1910) 6.]. Published in American Political Science Association Proceedings VI(1909) 100-108 and UTM 10 (February 1910) 173-83. 
Unverified: Introductory History of England. Toronto: Macmillan, 1909. [See correspondence between Wrong and Sir James Whitney, May and June 1910, Ontario Archives.]

\section{0}

Edited: (with H. H. Langton) Review of Historical Publications Relating to Canada [of the year 1909] Vol. XIV. University of Toronto, 1910. pp. 209.

Article: "Canada-History", Encyclopaedia Britannica, 11 th Ed., vol. 5 (1910) 156-159.

\section{1}

Book: Ontario High School History of England. Toronto: Morang, 1911.pp. viii, 536. [Substantially revised version of The British Nation (1903).] Revised Editions, Toronto: Macmillan, 1922, 1924, 1927.

Edited: (with H. H. Langton) Review of Historical Publications Relating to Canada [ of the year 1910 ] Vol. XV. University of Toronto, 1911. pp. 220.

Letter: "Concerning Flags" [Supports lowering of flag at sunset] Varsity 31 (8 December 1911) 2.

Address: "Relations of the Legislature to the Executive Power in Canada", December 1911, American Political Science Assoc. Published in American Political Science Assoc. Proceedings, Vol. VI, Supp. (1912) 173-80. [The Proceedings are bound with American Political Science Review.]

\section{2}

Edited: (with W.S. Wallace) Review of Historical Publications Relating to Canada [of the year 1911] Vol. XVI. University of Toronto, 1912. pp. 211.

Article: "Sir Daniel Wilson", The Arbor 3 (January 1912) 150-60.

Address: "Canada as an Adjunct of the United States" Toronto, 9 May 1912. [RBD].

Letter: [(Signed "G.M.W.") "A Kick" (re: allotment of rugby tickets) Varsity 32 (2 October 1912) 2.]

Address: [proposed toast to Quebec at University College Dinner at McConkey's Hall; H. Bourassa was speaker [ [see Varsity 32 (4 December 1912) 1] .

Address: to the American Society for the Judicial Settlement of International Disputes, Washington, 21 December 1912. [RBD].

\section{3}

Edited: (with W.S. Wallace) Review of Historical Publications Relating to Canada [of the year 1912] Vol. XVII. University of Toronto, 1913. pp. 240.

Article: "The Federation: General Outlines, 1867-1912", Canada and Its Provinces, edited by Adam Shortt and Arthur G. Doughty, Vol. VI, pp. 3-11. Toronto: Glasgow, Brook and Company, 1913-17, 23 vols. [Wrong was also one of the Associate Editors of Canada and Its Provinces] 
Article: "Sir Charles Moss" UTM 13 (January 1913) 127-9.

Address: "Problems of Collegiate Life", 13 January 1913, at Wycliffe College. [See Varsity 32 (17 January 1913) 3].

Article: "Cecil Rhodes and His Work", Arbor 4 (January 1913) 136-44.

Article: "St. Augustine [Quebec]", The University Magazine 12 (February 1913) 65-76.

Address: [On education, at University College, class of 1916; see Varsity 33 (1 December 1913) 3.]

\section{4}

Book: The Fall of Canada, A Chapter in the History of the Seven Years' War, Oxford: Clarendon Press, 1914. pp. 272.

Edited: (with H. H. Langton) for the Chronicles of Canada Series, Glasgow, Brook, 1915:

L.J. Burpee, Pathfinders of the Great Plains, a Chronicle of La Verendrye and his Sons, Vol. 19;

Thomas Chapais, The Great Intendant, a Chronicle of Jean Talon in Canada, 1665-1672, Vol. 6;

A.C. Laut, The 'Adventurers of England', a Chronicle of the Fur Trade in the North, Vol. 18;

Stephen Leacock, Adventurers of the Far North, a Chronicle of the Frozen Seas, Vol. 20;

W.B. Munro, The Seigneurs of Old Canada, a Chronicle of New World Feudalism, Vol. 5;

W.S. Wallace, The United Empire Loyalists, a Chronicle of the Great Migration, Vol. 13;

William Wood, The Passing of New France, a Chronicle of Montcalm, Vol. 10 ;

William Wood, The Winning of Canada, a Chronicle of Wolfe, Vol. 11.

Edited: (with H.H. Langton and W.S. Wallace) Review of Historical Publications Relating to Canada [of the year 1913] Vol. XVIII. Published for the University of Toronto by Glasgow, Brook, 1914.pp. 245.

Article: "Dominion of Canada", Cyclopedia of American Government, A.C. McLaughlin and A.B. Hart, eds., New York: Appleton, 1914, Vol. 1, pp. 210-14; "Canadian Provinces " Ibid., 214-15; "Canadian Parliament" Ibid., Vol. II, 615-16.

Letter: "A Canadian View of Ireland", The Times (London) (9. June 1914) 7. [see also Star (9 June 1914) 4].

Address: August 1914, sermon at Union Church, Murray Bay, [RBD] .

Address: September 1914, sermon at Union Church, Murray Bay [RBD].

Address: "Why Germany is at War", 14 October 1914. Published in Addresses Delivered Before the Canadian Club of Toronto 1914-1915, Vol. XII, Toronto: Warwick Brothers, 1915, 217-33.

Address: "The Germany of Bismarck", 19 October 1914 [one of a series of special lectures on the war; see UTM 15 (November 1914) 55-57].

Address: "The Germany of William II (26 October 1914) [see Varsity 34 (28 October 1914) 1; and "The Empire of William II" UTM 15 (December 1914) 101-3. 
Letter: The New York Times (28 November 1914) 12 [vs. editorial (23 November 1914) criticising Canada's prohibition of German newspapers].

Address: [On German culture] (30 November 1914) at Queen's Hall [see Varsity 34 (2 December 1914) 4.]

Address: ["The Possible Terms of Peace" in Addresses Delivered Before the Canadian Club of Montreal, Season 1914-15, n.d., pp. 131-8.

Unverified Address: [On the war], 23 October 1914, North York Teachers' Convention.

Unverified Address: "Germany and the War", 5 November 1914, Women's Canadian Club.

Unverified Address: "Germany and the War" Midland, Ontario [1914-15 Extension Department Lecture Series].

Unverified Address: "Germany's Reasons for War" Women's Canadian Club, Ottawa [1914-15 Extension Department Lecture Series] .

Unverified Address: "German Sea Power" Woodstock, Ontario [1914-15 Extension Department Lecture Series].

\section{5}

Edited: (with H. H. Langton) for the Chronicles of Canada Series, Toronto: Glasgow, Brook, 1915:

C. W. Colby, The Fighting Governor, a Chronicle of Frontenac, Vol. 7;

C. W. Colby, The Founder of New France, a Chronicle of Champlain, Vol. 3;

A. C. Laut, Pioneers of the Pacific Coast, a Chronicle of Sea Rovers and Fur Hunters, Vol. 22;

Stephen Leacock, The Dawn of Canadian History, a Chronicle of Aboriginal Canada, Vol 1;

Stephen Leacock, The Mariner of St. Malo, a Chronicle of the Voyages of Jacques Cartier, Vol. 2;

T. G. Marquis, The War Chief of the Ottawas, a Chronicle of the Pontiac War, Vol. 15;

Sir Joseph Pope, The Day of Sir John Macdonald, a Chronicle of the First Prime Minister of the Dominion, Vol. 29;

E. T. Raymond, Tecumseh, a Chronicle of the Last Great Leader of his People, Vol. 17;

W. S. Wallace, The Family Compact, a Chronicle of the Rebellion in Upper Canada, Vol. 24;

W. S. Wallace, The War with the United States, a Chronicle of 1812 , Vol. 14;

L. A. Wood, The Red River Colony, a Chronicle of the Beginnings of Manitoba, Vol. 21;

L. A. Wood, The War Chief of the Six Nations, a Chronicle of Joseph Brant, Vol. 16;

William Wood, All Afloat, a Chronicle of Craft and Waterways, Vol. 31 ; 
William Wood, The Great Fortress, a Chronicle of Louisbourg, 17201760, Vol. 8.

Edited: (with H.H. Langton and W.S. Wallace) Review of Historical Publications Relating to Canada [of the year 1914] Vol. XIX. Published for the University of Toronto by Glasgow, Brook, 1915 pp. 247.

Pamphlet:The War Spirit of Germany, Toronto: Oxford (1915) 27 pages. Condensed by L. Kohr, reprinted in Globe and Mail (16 June 1941) 6.

Article: "Canada's Part in the War" "The Varsity" War Supplement (1915) 37.

Article: "Elba, a hundred years after", Royal Society of Canada, Proceedings and Transactions, 3rd Series, IX, Section II, (1915) 205-22.

Address: "Germany's Reasons for War" [ one of a series of local lectures delivered in Toronto and in Ontario under the auspices of Department of Extension, during the year 1915-16.]

Address: "Some phases of the War", 11 January 1915, to Ministerial Association [The Toronto Daily News (11 January 1915) 1.

Article: "William Allaire Shortt" UTM 15 (February 1915) 281.

Address: "Napoleon at Elba: The failure of world conquest" [see Varsity 34 (24 February 1915) 2.]

Article: "How England has used her sea power", The New York Times (18 March 1915) 10 [opposes C. W. Eliot's proposal for a European Union; says a union of free nations would be better.]

Letter: "What is piracy?" The New York Times (29 March 1915) 8. [German submarines.]

Letter: "At Least Once" The New York Times (30 March 1915) 10 [refutes a statement of Dr. Dernburg re insularity of Sir Edward Grey.]

Letter: “An Election Opposed", The Toronto Daily News (13 April 1915) 6. [Edit. reply in Ibid. (14 April 1915) 6.]

Letter: "To Avert an Election" [announcing public meeting, Burwash Hall, 23 April] The Toronto Daily News (19 April 1915) 6.

Letter: "No Election Now", Globe (13 April 1915) 4; "Truce and No Election", Star (13 April 1915) 4.

Letter: "To Avert an Election" [announcing Public meeting] Star (19 April 1915) 13. [Description of meeting in Star (24 April 1915) 5.]

Article: "The Cruel Outlook for Peace in Europe", The New York Times (8 May 1915) 14. [Reply by W. F. Cooley (15 May 1915) 12.]

Review: J. Boyd, Sir George Etienne Cartier, Bart., His Life and Times: A Political History of Canada from 1814 until 1873, AHR 21 (October 1915) 167-69.

Article: "The Urgency of Economy", Globe (22 November 1915) 6; Mail (20 November 1915) 12; World (19 November 1915). [Ed. reply World (23 November 1915); see also Henry Britton, Mail (23 November 1915) 10.] 
Article: "Canada: An Outline and Bibliography of its History", Pt. 1. Published by the League of the Empire in The Federal Magazine (December 1915) 84143.

Address: "The growth of nationalism in the British Empire", (31 December 1915). Published in AHR 22 (October 1916) 45-57.

Unverified Article: [Outline of the proposals, Federal planning commission for Ottawa and Hull, 1915.]

\section{6}

Edited: (with H. H. Langton) for the Chronicles of Canada Series, Toronto: Glasgow, Brook, 1916:

A. H. U. Colquhoun, The Fathers of Confederation, a Chronicle of the Birth of the Dominion, Vol. 28;

A. D. de Celles, The 'Patriotes' of '37, a Chronicle of the Lower Canadian Rebellion, Vol. 25;

A. G. Doughty, The Acadian Exiles, a Chronicle of the Land of Evangeline, Vol.9;

A. C. Laut, The Cariboo Trail, a Chronicle of the Gold Fields of British Columbia, Vol. 23;

A. M. MacMechan, The Winning of Popular Government, a Chronicle of the Union of 1841, Vol. 27;

T. G. Marquis, The Jesuit Missions, a Chronicle of the Cross in the Wilderness, Vol. 4;

O. D. Skelton, The Day of Sir Wilfrid Laurier, a Chronicle of Our Own Times, Vol. 30;

O. D. Skelton, The Railway Builders, a Chronicle of Overland Highways, Vol. 32;

William Wood, The Father of British Canada, a Chronicle of Carleton, Vol. 12.

Edited: (with H. H. Langton and W. S. Wallace) Review of Historical Publications Relating to Canada [of the year 1915] Vol. XX. Published for the University of Toronto by Glasgow, Brook, (1916) 224 pp.

Article: "Canada: An Outline and Bibliography of its History," Pt. 2. Published by the League of the Empire in The Federal Magazine (January-February 1916) 849-50.

Article: "Edward Joseph Kylie" UTM 16 (June-July 1916) 424.

Review: B. Willson, The Life of Lord Strathcona and Mount Royal, 2 Vol.; W.T.R. Preston, Strathcona and the Making of Canada, AHR 21 (July 1916) 804-806.

Letter: [union government] Globe (24 November 1916) 4; Star (24 November 1916) 5. [Reply Star (29 November 1916) 14 by F. D. Kerr (pro Wrong).] 
Article: “James Henry Oldham, B.A." UTM 17 (December 1916) 93.

Address: "Fifty Years of Federation in Canada" (8 December 1916). Published in the Canadian Club of Ottawa, Ottawa, Mortimer (1917) 128-140. [Note: Address with similar title given to Ingersoll Canadian Club, (ca. 13 October 1916); Men's Club of Deer Park Christ Church (23 November 1916); Royal Canadian Institute (ca. 21 January 1917); Hamilton Canadian Club and Women's Canadian Club (Hamilton) (24 January 1917).]

Address: ["Germany's Reasons for War", one of a series of local lectures delivered in Toronto and through Ontario under the auspices of the Department of Extension, during the year 1916-17.]

Unverified Address: "Canada 50 Years after Confederation" Women's Canadian Club, Guelph, Ontario [1916-17 Extension Department Lecture Series].

\section{7}

Edited: (with H.H. Langton and W.S. Wallace) Review of Historical Publications Relating to Canada [of the year 1916] Vol. XXI. Published for the University of Toronto by Glasgow, Brook 1917. $192 \mathrm{pp}$.

Article: "The bilingual question", The new era in Canada: Essays Dealing with the Upbuilding of the Canadian Commonwealth, edited by J.O. Miller. Toronto: Dent, (1917) pp. 229-59.

Article: "When the men come back", The Varsity Magazine Supplement (1917) 123-4.

Address: [Canada is badly organized and educated], to Toronto Ministerial Association [see Star (22 January 1917) 4; and Mail (23 January 1917)] .

Article: "The creation of the federal system in Canada", The Federation of Canada, 1867-1917 [four lectures delivered in the University of Toronto in March 1917 to commemorate the Fiftieth Anniversary of the Federation.] by George M. Wrong, Sir John Willison, Z.A. Lash, and Sir Robert Falconer, Toronto: Oxford University Press (1917) 1-38. [See Varsity 36 (9 March 1917) 1.]

Letter: "The Round Table in Canada", Globe (30 March 1917) [Accompanied by an editorial commenting on Wrong's letter. See also, "They are but Students", Star (31 March 1917) 3.]

Address: "The Duties of Citizenship in Canada" (5 April 1917) at Convocation Hall. [First of a series of lectures on Citizenship. See response in Mail (21 April 1917) 20.]

Address: "Fifty years of federation - a look backward and a look forward" [read at May meeting, 1917, published in Royal Society of Canada, Proceedings and Transactions, 3rd series, XI, section II (1917) 61-70] .

Article: "Paris in 1871", University Magazine, 16 (December 1917) 559-72. 


\section{8}

Book: The Conquest of New France: A chronicle of the colonial wars, Chronicles of America series, X, New Haven: Yale University Press, 1918 , pp. $x, 246$.

Address: "The Revised Jewish State", 28 January 1918. Menorah Society [see Varsity 37 (30 January 1918) 1] .

Letter: "Replies to 'American Jurist", The New York Times (29 January 1918) 14 [see "America After the War ... VI - Canada" by an American Jurist, The New York Times (12 January 1918) 10] .

Article: "Paris in 1794", The University Magazine, 17 (February 1918) $28-44$.

Address: "Civil Service Reform", 28 February 1918. Published in Empire Club of Canada, Addresses Delivered to the Members During the Session 1917-18, Toronto: Warwick 1919, pp. 131-39.

Address: [History of Canada] 10 October 1918. Women's Canadian Historical Society [see World (11 October 1918) 7].

\section{9}

Edited: (with H.H. Langton and W.S. Wallace) Review of Historical Publications Relating to Canada [of the years 1917 and 1918] Vol. XXII. University of Toronto, 1919.pp. 203.

Article: "Relations Between the United States and Canada", The Historical Outlook [Social Studies for Teachers] X (January 1919) 5-8.

Article: "The Outlook in England", Globe (12 June 1919) 6.

Letter: "The Epsom Incident", The Times (London) (24 June 1919) 8 [re: riot by Canadian soldiers, 17 June 1919].

Article: "Old England and New Canada", The Khaki Varsity Souvenir Number (July 1919) 56-58 [a copy in PAC, Underhill papers, 89] .

Unverified Address: "Canada's Status in the League of Nations" (Varsity Diggers Club).

\section{0}

Edited: (with H.H. Langton) for the Chronicles in Canada Series, Glasgow, Brook, 1920: W.L. Grant, The Tribune of Nova Scotia, A Chronicle of Joseph Howe, Vol. 26.

Article: "Canada and the League of Nations. The Dominion Cannot Yield Her Place to Satisfy any Demand of Our Senate", The New York Times (27 February 1920) 12 [summary and comments in Globe (28 February 1920) 42].

Article: "Canada and the Imperial War Cabinet", Canadian Historical Review 1 (March 1920) 3-25. 
Review: Benjamin Sulte, George-Etienne Cartier. Augmente et publié par Gerard Malchelosse, CHR 1 (March 1920) 83-5.

Review: A.B. Keith, ed., Selected Speeches and Documents on British Colonial Policy, 1763-1917, 2 vols. CHR I (March 1920) 111-12.

Quoted: [on the cancelling of a lecture by $\mathbf{J}$ ane Addams, due to pressure from the I.O.D.E. and others] Varsity 39 (1 March 1920) 1.

Address: "What it means to be a Nation", 4 March 1920, to Daughters of Canada [see Globe (5 March 1920) 10; World (5 March 1920)].

Address: "Did the British Empire Cease to Exist on August 4th, 1914?" 8 March 1920. Published in Addresses Delivered Before the Canadian Club of Toronto, Season of 1919-20 XVII, 1920, 259-67 [see Mail (9 March 1920); Globe (9 March 1920)].

Address: [the League of Nations] 29 March 1920, Board of Trade Young Men's Club [see Globe (30 March 1920) 3] .

Review: W.R. Riddell, Old Province Tales: Upper Canada, 1920, CHR I (December 1920) 406-8.

Unverified Address: "The Christian as Citizen", February 1920 [at St. James Cathedral Parish House].

1921

Book: Ontario Public School History of Canada, Toronto: Ryerson Press, 1921, pp. 365. [Issued in British Columbia under the title History of Canada, and in Saskatchewan under the title Public School History of Canada, Ryerson, 1921. Reprinted under the title Canada, a Short History, Ryerson, 1924]. [Criticised by R. Stothers, Telegram (16 February 1922) 12; also see Mail (7 January 1922) 16.]

Book: Ontario Public School History of England, Toronto: Ryerson Press, 1921, pp. viii, 384.

Book: Washington and His Comrades in Arms: A Chronicle of the War of Independence, Chronicles of America Series, XII, New Haven: Yale University Press, 1921. pp. xii, 295.

Book: The United States and Canada, a Political Study, Wesleyan University, George Slocum Bennett Foundation lectures, second series, 1919. 1920. New York and Cincinnati: Abingdon Press, 1921. pp. 191.

Address: [Canada's political development] 21 March 1921, Hamilton Canadian Club [see Hamilton Herald (22 March 1921)].

Address: [on France before and after the war] to McAll Mission [see The Evening Telegram (1 April 1921) 18.]

Review: H.G. Wells, The Outline of History, Being a Plain History of Life and Mankind, 2 vols., CHR 2 (June 1921) 190-92.

Review: Victor Ross, A History of the Canadian Bank of Commerce, with an Account of the other Banks which now form Part of its Organization, Vol. I, CHR 2 (September 1921) 290-94. 
Address: "The Framework of Government in Canada", 19 October and 2 November 1921, Bankers' Educational Association, Published in Journal of the Canadian Bankers' Association [Canadian Banker] 29 (January 1922) 219-26.

Letter: "Initiation Rites", Varsity 41 (14 November 1921) [see also "Professor Wrong on Initiations", UTM 22 (December 1921) 96] .

Article: "Democracy in Canada", CHR 2 (December 1921) 315-32.

Address: "Canada, a Nation", 11 December 1921, Labor Forum [see Mail (12 December 1921) 5].

Unverified Address: ca. May 1921, Lindsay Red Cross.

Unverified Address: [Canada's status] 1921, Montreal Women's Club.

Unverified Address: "Canada as a Nation" (Runnymede Travel Club?) Toronto [1921-22 Extension Department Lecture Series].

\section{2}

Address: "The Washington Conference", 31 January 1922, Convocation Hall [see "Who Say Frenchmen Lack Humour?", Globe (1 February 1922) 9; Telegram (1 February 1922) 10; Mail (1 February 1922) 4]; [Address on same topic given to Electric Club, 8 February 1922, and College Heights Women's Educational Association, 1 March 1922; see Mail (9 February 1922) 5 and clippings in University of Toronto Archives, Biographical File.]

About: "The Spotlight", Star (1 February 1922) 6.

Address: 10 February 1922 [first meeting of graduate students; see Varsity 41 (13 February 1922) 1.]

Letter: "The Empire's Title Deeds", Globe (16 February 1922) 4 [commenting on Churchill's speech].

Address: "Canada's present position in the British Empire", 27 February 1922, Board of Trade Young Men's Club [Mail (28 February 1922) 7].

Review: E.C. Burnett, ed., Letters of Members of the Continental Congress, Vol. I, CHR 3 (March 1922) 68-72.

Address: "The History of the Church of England", 7 March 1922, St. Barnabas' Church [Globe (8 March 1922) 15]

Address: "Canada and the Problem of Assimilation", 12 March 1922, Temple Centre of Holy Blossom Synagogue [Star (13 March 1922) 5; Mail (13 March 1922) 4; Globe (13 March 1922) 11]. [Wrong commented on the daily press as an influence of assimilation, and stated that fifteen minutes a day was enough time to spend on that kind of reading. See editorial comments Telegram (18 March 1922) 24 and (27 March 1922) 16; Star (16 March 1922) 6; Globe (14 March 1922) 4.]

Address: [Response to toast "The Empire"] 24 April 1922, St. George's Society [Globe (25 April 1922) 13].

Letter: [on prohibition in Canada; originally sent to the New Statesman] Social Welfare 4 (May 1922) 177-8. 
Review: Major General R.H. Mahon, The Life of General, The Hon. James Murray, a Builder of Canada: with a biographical sketch of the family of Murray of Elibank, CHR 3 (June 1922) 195-99.

Review: Sir J. Pope, ed., Correspondence of Sir John Macdonald, First Prime Minister of the Dominion of Canada, AHR 27 (July 1922) 799-801.

Address: "International Relations and Government: 19 September 1922, Student Christian Movement Conference [Globe (20 September 1922) 3].

Letter: "Regulation Seventeen", Globe (6 December 1922).

\section{3}

Article: (Unsigned) [on National Student Conference, December 28, 1922 January 2, 1923] Varsity 42 (January 12, 1923) 1.

Article: "The Champlain Society", UTM 23 (March 1923) 274-5.

Review: C.H. Van Tyne, The Causes of the War of Independence, Being the First Volume of the History of the Founding of the American Republic, CHR 4 (March 1923) 60-63.

Review: O.D. Skelton, Life and Letters of Sir Wilfrid Laurier and J.W. Dafoe, Laurier, a Study in Canadian Politics, AHR 28 (April 1923) 570-73.

Address: [on Francis Parkman] 17 November 1923, Canadian Authors' Association [see Globe (19 November 1923) 12].

Article: "Francis Parkman", CHR 4 (December 1923) 289-303.

Review: H.E. Egerton, The Causes and Character of the American Revolution, CHR 4 (December 1923) 338-42.

\section{4}

Address: "The Present Situation in Europe", 15 January 1924, Convocation Hall and CFCA radio [see Varsity 43 (16 January 1924) 1; Star (16 January 1924) 2; Mail (16 January 1924) 4; UTM 24 (February 1924) 216-18]. [For replies, see "Severing with France" [editorial] The Christian Guardian (Toronto) 95 (23 January 1924) 4; and interview by Rev. Capt. J.B. Paulin, Star (16 January 1924) 28.]

Address: "Student Conditions in Europe", 16 January 1924 [see Varsity 43 (17 January 1924) 1]

Article: "Our Legislative Mills, VIII. A Contrast: the single house legislature of Ontario", National Municipal Review, 13 (March 1924) 169-72.

Address: "The European Situation", 13 March 1924, Published in Empire Club of Canada, Addresses Delivered to the Members during the Year 1924, Toronto: Macoomb, 1924, 125-35.

Address: 25 April 1924, Women's Canadian Club, Toronto [see Globe (26 April 1924) 18; and "Historical Truths and Patriotism" Canadian Magazine 63 (September 1924) 319-20] .

Address: "Prospects of Peace in Europe", 28 April 1924, Methodist Ministerial Association [see Globe (29 April 1924) 14] .

Address: [election in the United States] 4 November 1924, Alumni Federation lecture [see Varsity 44 (5 November 1924) 1; Globe (5 November 1924) 11: Mail (5 November 1924) 5, UTM 25 (December 1924) 113-14)]. 
Address: "The teaching of the history and geography of the British Empire". August 1924, British Association for the Advancement of Science. Published in CHR 5 (December 1924) 297-313.

Address: "That in the interests of society the truth of history should sometimes be perverted" debate, 10 December 1924 [see Varsity 22 (11 December 1924) 1, 4].

Review: J.C. Bracq, The Evolution of French Canada, CHR 5 (December 1924) $365-6$.

Address: "The Evolution of the Foreign Relations of Canada", 29 December 1924, American Historical Association [published in CHR 6 (March 1925) 4-14].

\section{5}

Article: "An Appreciation", Ellen Mary Knox, Toronto: Havergal College, 1925, pp. 33-39.

Review: C.M. Andrews, The Colonial Background of the American Revolution: Four Essays on American Colonial History, and A. Nevins, The American States during and after the Revolution, 1775-1789, CHR 6 (March 1925) 714.

Address: "The two races in Canada", 21 May 1925. Published in Canadian Historical Association, Annual Report (1925) 21-7.

About: "Le Prof. Wrong et 1'Unité Nationale", Le Droit (Ottawa), 8 July 1925 [re: Wrong, speech in Orillia by Sir George Foster, and Association Canadienne-Française d'Education d'Ontario] .

Article: "Opinion in Canada", New Statesman XXV (4 July 1925) 330-32 and Star (18 July 1925). [Response to Harold Spender's article, "Will the Empire Hold Together?", Contemporary Review 127 (April 1925) 409-16; Spender's reply is in New Statesman XXV (18 July 1925) 391-2, and Wrong's response is in Ibid. (8 August 1925) 471-2. See also Star (22 July 1925) 6 and (20 August 1925) 6.]

Address: October 13, 1925, Literary Society, University College [see Varsity 45 (14 October 1925) 1].

Review: John J. Wynne, S.J., The Jesuit Martyrs of North America: Isaac Jogues, John de Brebeuf, Gabriel Lalemont, Noel Chabanel, Anthony Daniel, Charles Garnier, Rene Goupil, John Lalonde, CHR 6 (December 1925) 349-51.

Quoted: "Profisms", Varsity 45 (5 November, 26 November, 3 December, 1925).

Address: "The British and American Constitutions", 26 November 1925, Toronto Women's Liberal Association [Star (27 November 1925) 26; Globe (27 November 1925)] .

Quoted: "No Sympathy" [with those who wish to perpetuate war feeling re: crests in Hart House] Telegram (3 December 1925) 7 [see Varsity 45 (27 November 1925) 166] .

Unverified Address: [on Sir William Osler] 1925, Northumberland and Durham Society of Physicians. 


\section{6}

Address: "Nationalism in Canada", 20 April 1926,. Published in Journal of the Royal Institute of International Affairs V (July 1926) 177-94.

Article: "The Problem of Status", Manitoba Free Press (Winnipeg) (17 July 1926) 17 [editor's comment, Ibid., p. 11].

Review: J.F. Jameson, The American Revolution Considered as a Social Movement, CHR 7 (September 1926) 250-5].

Article: "The Debts to the United States", Globe (27 September 1926) 4.

Address: [recommends students spend less on cigarettes, more on books] see Varsity 46 (4 October 1926) 5.

Letter: "War Guilt", Globe (18 November 1926) 4.

Address: "The Need to Understand French Canada", 23 November 1926, Women's Canadian Club, Globe (24 November 1926) 16.

Quoted: [re: Ontario Temperance Act] Mail (24 November 1926) 5.

Review: E.C. Burnett, ed., Letters of Members of the Continental Congress, Vol. 3, CHR 7 (December 1926) 338-40.

Address: "Canada's Problem of Equality with Great Britain", 9 December 1926. Published in Empire Club of Canada, Addresses Delivered to the Members During the Year 1926, Toronto: Hunter-Rose, 24 (1927) 299-310. [Editorial comment on speech, Globe (10 December 1926) 4.]

\section{7}

Article: "Professor W.J. Alexander", UTM 27 (January 1927) 151-2.

Address: "Wolfe and Montcalm" [an introduction to the film based on his Conquest of New France made by Yale University Press] 24 February 1927. [See Empire Club of Canada, Addresses Delivered to the Members During the Year 1927, Toronto: Hunter-Rose, 1928, p. 39; Globe 25 February 1927; Star (24 February 1927) 3. Letter criticizing omission of Wolfe's recitation, and Wrong's reply, Star 5 March 1927.]

Review: J.J. Jusserand, et. al, The Writing of History; John Fortescue, The Writing of History; and John Buchan, Homilies and Recreations, CHR 8 (March 1927) 56-60.

Review: B.L. Pierce, Public Opinion on the Teaching of History in the United States, CHR 8 (March 1927) 60-62.

Review: Cecil Headlam, ed., Calendar of State Papers: Colonial Series, America and West Indies, CHR 8 (March 1927) 65-66.

Review: Brig. Gen. Sir Percy Sykes, The Right Honourable Sir Mortimer Durand, a Biography, CHR 8 (March 1927) 76-77.

About: "Prof. G.M. Wrong to Retire from University Faculty", Star (9 March 1927) 12.

Address: "The Historian's Problem", May 1927, Presidential Address. Published in Canadian Historical Association Report (1927) 5-7.

Article: "Problems issuing from Confederation", 12 May 1927. Published in Addresses Delivered Before Canadian Club of Toronto, Season of 1927-28 XXV (1927) 3-13. 
Article: "Canada's Sixty Years of Confederation", Current History XXVI (August 1927) 721-6.

Review: John Squair, The Townships of Darlington and Clarke, including Bowmanville and Newcastle, Province of Ontario, Canada, CHR 8 (September 1927) 262-4.

\section{8}

Book: The Rise and Fall of New France, 2 volumes, Toronto: Macmillan, 1928.

About: "Modern Makers of Canada - Prof. G.M. Wrong", Manitoba Free Press (25 January 1928) 13.

Review: C. Wittke, $A$ History of Canada, AHR 34 (April 1929) 631-33.

About: [recent trip to Europe] Star (21 April 1928) 4.

Review: J.L. Morison, The Eighth Earl of Elgin: a chapter in Nineteenth Century Imperial History, CHR 9 (June 1928) 175-8.

Debate: [modern journalism] 31 October 1928 [Globe (1 November 1928) 14].

Review: W.T. Waugh, James Wolfe, Man and Soldier; J.T. Findlay, Wolfe in Scotland, in the ' 45 and from 1749 to 1753, CHR 9 (December 1928) $341-5$.

1929

Book: (with Chester Martin and W.N. Sage) The Story of Canada, Toronto: Ryerson, 1929, pp. xii, 380. [Wrong wrote: Part I, "When Canada was New France", Part II, "Canada as a British State", and Part V, "Our Own Times". Many portions are revisions of Wrong's Ontario Public School History of Canada, Ryerson, 1921.]

Book: Britain's History, Toronto: Copp Clark, 1929, pp. vii, 396. [Revised version of Ontario Public School History of England, Ryerson, 1921].

Address: "Canadian Historical Backgrounds", 20 January 1929, Canadian Authors' Association [see Globe (21 January 1929); Mail (21 January 1929) 5] .

Address: "Canadian History as a Background for Canadian Literature", 26 January 1929, Canadian Literature Club [see Mail (28 January 1929) 5].

Review: G.B. Parks, Richard Hakluyt and the English Voyages, edited with an introduction by J.A. Williamson, CHR 10 (June 1929) 159-60.

Review: C.H. Van Tyne, The War of Independence: American Phase, Vol. II of $A$ History of the Founding of the American Republic; and W.C. Abbott, New York in the American Revolution, CHR 10 (September 1929) 250-53.

Review: J.H. Rose, ed., The Cambridge History of the British Empire, Vol. I, The Old Empire from the Beginnings to 1783, CHR 10 (September 1929) 259-61.

Review: J. Holland Rose, ed., The Cambridge History of the British Empire, Vol. I, The Old Empire from the Beginning to 1783, AHR 35 (October 1929) 103-5. 
About: [recent trip to China] Star (10 January 1930) 2.

Address: [China and Japan] 27 January 1930, Foreign Affairs Club [see Varsity 49 [misnumbered 48] (28 January 1930) 1-2].

Address: "The Position of Canada in the Relations of the British Empire with the United States", February 1930, Cleveland, Ohio. [RBD].

Review: H.H. Langton, Sir Daniel Wilson: A Memoir, CHR 11 (March 1930) 63-66.

Address: [Conference on Pacific Relations] 24 March 1930, Board of Trade Club [see Mail (25 March 1930) 5].

Address: "What Would United States Naval Parity with Great Britain Mean for Canada?", 10 April 1930. Published in Empire Club of Canada, Addresses Delivered to the Members During the Year 1930, Toronto: Hunter-Rose, XVIII, 1931, 153-64 [see Globe (11 April 1930) 14; Telegram (11 November 1930) 6].

Review: W.C. Abbott, New York in the American Revolution; and C.H. Van Tyne, The War of Independence: American Phase being the second volume of $A$ History of the Founding of the American Republic, CHR 11 (September 1930) 250-53.

Address: "How Democracy is Working in Canada", 2 November 1930, Canadian Club of Ottawa [see Globe (3 November 1930) 1].

Review: J.B. Condliffe, Problems of the Pacific 1929: Proceedings of the Third Conference of the Institute of Pacific Relations, Nara and Kyoto, Japan, October 23 to November 9, 1929, CHR 11 (December 1930) $361-2$.

\section{1}

Review: G. Hanotaux, et. al., Histoire des Colonies Française et de l'Expansion de la France dans le Monde, AHR 36 (January 1931) 372-4.

Address: [on French Canada] 14 January 1931, Lyceum Club and Women's Art Association [Globe (15 January 1931) 14; Mail 15 January 19311.

Address: "Our Present Outlook", 6 November 1931, Alumni Association, University College. Published in UTM 32 (December 1931) 107-13.

Review: Shane Leslie, Memoir of John Edward Courtenay Bodley, CHR 12 (December 1931) 445-6.

1932

Letter: "Canadians Puzzled", The New York Times (25 November 1932) 14. [Comments on proposals by W.G. McAdoo and P.G. Ten Eyck that England should cede territory.]

Address: "The Historian and Society", December 1932, American Historical Association. Published in CHR 14 (March 1933) 4-8.

Unverified Address: "Recent Discoveries in Canadian History", 18 February 1932, [U of T Broadcasting Program]. 
Review: H.P. Biggar, ed., The Works of Samuel de Champlain, Vol. IV, 16081620, AHR 38 (January 1933) 319-20.

Address: "Our Defective Civilization", 11 March 1933, Canadian Club of Ottawa [see Star (13 March 1933) [includes introductory remarks by the President]. [RBD]

Address: "Canada's Present Outlook", (April?) 1933, radio address. [RBD]

Review: Allen French, General Gage's Informers: New Material upon Lexington and Concord, Benjamin Thompson as Loyalist and The Treachery of Benjamin Church, Jr.; and E.C. Burnett, ed., Letters of Members of the Continental Congress, Vol. VI, CHR 14 (September 1933) 325-27.

Review: E.W. Spaulding, New York in the Critical Period, 1783-1789, CHR 14 (September 1933) 327-8.

Address: "Revolution and Reaction", 9 September 1933 [a paper read before the Liberal-Conservative summer school, Newmarket]. Published in Canadian Problems; as seen by Twenty Outstanding Men of Canada, Toronto: Oxford, 1933, 3-16.

Address: “Three great democracies - after many years", 16 September 1933, dedication of the Carillon Bridge Monument, Ticonderoga. Published in New York History XV (January 1934) 27-30.

Address: [foreign policies of Great Britain and the United States] (November 1933?) radio address. [RBD]

Address: "Britain and United States Foreign Policies", 28 November 1933, radio address under the auspices of the National Council of Education [see Star (28 November 1933) 20].

\section{4}

Address: "The background of the Loyalist movement, 1763-1793", 17 February 1934, Ontario Historical Society, Trinity College. Published in Ontario History XXX (1934) 171-80.

Review: Tyler Bennett, John Hay: From poetry to politics, CHR 15 (June 1934) 207-09.

Address: "The Historian's Interest in Museums", 1 June 1934, Museums Association of America, Toronto, [RBD].

Review: Paul Van Der Vrecken de Bormans, René de Kerallain, 1849-1928: Biographie; and Correspondance de René de Kerallain, 1889-1928, Vol. I, CHR 15 (September 1934) 314-15.

Article: "What has befallen us?", University of Toronto Quarterly 4 (October 1934) 34-54.

Letter: "Bad Manners", Star (3 October 1934) 6 [correcting Star article re: N.M. Butler article on manners, see Star (2 October 1934)]

\section{5}

Book: Canada and the American Revolution: The disruption of the first British Empire, Toronto: Macmillan, 1935. pp. xii, 497. Reprinted 1968, Cooper Square Publishers, New York.

Address: Introduction to "The Historical Background of Present Problems and Attitudes", 19 June 1935, Conference on Canadian-American Affairs 
at the St. Lawrence University. Published in Proceedings, W.W. McLaren, A.B. Corey, and R.G. Trotter, eds., Boston: Ginn and Company, 1936, 129-31.

1936

Article: "The beginnings of historical criticism in Canada: A retrospect, 18961936", CHR 17 (March 1936) 2-8 [editor's comment, Ibid., 1-2] .

\section{7}

Review: André Siegfried, Canada, translated by H.H. Hemming and D. Hemming, CHR 18 (September 1937) 327-9.

\section{8}

Book: The Canadians: The story of a People, Toronto: Macmillan, 1938, pp. $x, 455$.

Pamphlet: The Chronicle of a Family (a mimeographed pamphlet "for private use only"), 1938, pp. v, 62.

Review: J.C. Webster, 'Thomas Pickon' The Spy of Beauséjour: an account of his career in Europe and America with many original documents, translated by A. Webster, CHR 19 (March 1938) 70-1.

About: [Fiftieth anniversary of Department of Political Economy] [see Varsity 57 (11 March 1938) 1,4].

\section{9}

Edited: The Long Journey to the Country of the Hurons, by Father Gabriel Sagard, translated by H.H. Langton, Toronto: Champlain Society, 1939. pp. xii, 411.

About: Chester Martin, "Professor G.M. Wrong and History in Canada" in Ralph Flenley, ed., Essays in Canadian History Presented to George Mackinnon (sic) Wrong for his Eightieth Birthday, Toronto: Macmillan, 1939, pp. 1-23.

Article: "The Historical Background", Canada, London: The London Times, 1939, 11-17. [Reprinted from "The Canada Number" of The Times (London) (15 May 1939)] .

Article: "The Founding (of Ridley College)", Acta Ridleiana (Christmas, 1939) 13-21.

\section{0}

Translated: A. Siegfried, What the British Empire Means to Western Civilization (Oxford Pamphlets on World Affairs, No. C4) Toronto: Oxford University Press, 1940. pp. 28.

Article: "Is the U.S. fooled about this war?" Saturday Night LV (3 Fe"bruary 1940) 3.

About: [Fergus News-Record (8 February 1940)].

About: [A.R. Ford "Over the Week-End"] London Evening Free Press (29 January 1940).

\section{W. DUNCAN MEIKLE}

